\title{
PENERAPAN MODEL PEMBELAJARAN KOOPERATIF TIPE ARTIKULASI UNTUK MENINGKATKAN HASIL BELAJAR FISIKA SISWA PADA KELAS VIIIB SMP NEGERI 2
} MARAWOLA

\author{
Hasmiati Pese ${ }^{1}$, Hendrik Arung Lamba ${ }^{2}$ dan Muhammad Ali ${ }^{3}$ \\ Email: hasmiatiikamafistu@ymail.com \\ Program Studi Pendidikan Fisika, Jurusan Pendidikan MIPA, Universitas Tadulako \\ Jl. Soekarno Hatta KM.9 Kampus Bumi Tadulako Palu - Sulawesi Tengah
}

\begin{abstract}
Abstrak - Penelitian ini bertujuan untuk meningkatkan hasil belajar fisika siswa. Masalah yang diteliti adalah rendahnya hasil belajar siswa pada mata pelajaran IPA Fisika. Alternatif pemecahan masalah adalah menerapkan model pembelajaran kooperatif tipe artikulasi. Subyek penelitian ini adalah siswa kelas VIII B SMP Negeri 2 Marawola dengan jumlah siswa 19 orang. Penelitian ini menggunakan penelitian tindakan kelas yang dilaksanakan dalam dua siklus dengan materi pokok bunyi, masingmasing siklus meliputi 4 tahap: (i) perencanaan (ii) pelaksanaan tindakan (iii) observasi (iv) refleksi. Penerapan model pembelajaran kooperatif tipe artikulasi dapat meningkatkan hasil belajar fisika siswa kelas VIII B SMP Negeri 2 Marawola. Hal ini dapat dilihat pada peningkatan hasil belajar siswa dari siklus I ke siklus II. Untuk hasil belajar siklus I diperoleh nilai ketuntasan belajar klasikal sebesar $73,68 \%$ dan daya serap klasikal sebesar $72,98 \%$. Sedangkan pada siklus II diperoleh nilai ketuntasan belajar klasikal sebesar $89,47 \%$ dan daya serap klasikal sebesar $85,26 \%$ yang artinya sudah melebihi standar ketuntasan belajar siswa. Peningkatan ketuntasan belajar klasikal dan daya serap klasikal dari siklus I ke siklus II sebesar $21,43 \%$ dan $16,82 \%$. Hasil observasi aktivitas siswa dan guru pada siklus I yaitu cukup dan baik, sedangkan pada siklus II observasi aktivitas siswa dan guru berada pada kategori baik dan sangat baik
\end{abstract}

Kata Kunci: Model Pembelajaran Kooperatif; Kooperatif Tipe Artikulasi; Hasil Belajar Fisika; dan Bunyi.

\section{PENDAHULUAN}

Proses belajar mengajar dikatakan berhasil apabila hasilnya membawa perubahan yang artinya dalam proses belajar mengajar, guru dan siswa dituntut untuk menghasilkan perubahan dalam pengetahuan, kemampuan, nilai, sikap dan sifat-sifat pribadi. Agar dapat terwujud maka proses pembelajaran itu harus berlangsung dengan efektif dan efesien. Pelaksanaan pembelajaran di dalam kelas merupakan salah satu tugas utama guru dan pembelajaran dapat diartikan sebagai kegiatan yang ditujukan pada siswa. Dalam proses pembelajaran masih sering ditemui adanya kecenderungan meminimalkan keterlibatan siswa. Dominasi guru dalam proses pembelajaran menyebabkan kecenderungan siswa lebih bersifat pasif sehingga mereka lebih banyak menunggu sajian guru dari pada mencari dan menemukan sendiri pengetahuan, keterampilan atau sikap yang mereka butuhkan.

Berdasarkan hasil wawancara dengan guru mata pelajaran fisika di SMP Negeri 2 Marawola menunjukan bahwa upaya pembelajaran fisika pada siswa SMP Negeri 2 Marawola belum mencapai hasil yang maksimal (masih rendah) khususnya pada kelas VIII B salah satunya adalah proses pembelajaran fisika tidak berlangsung timbal balik. Guru hanya memfokuskan diri pada penyampaian materi sedangkan siswa disibukkan mencatat materi yang disampaikan oleh guru sehingga membuat siswa kesulitan mengembangkan ide serta 
menggali pengetahuannya sendiri. Guru menjadi pusat pembelajaran sedangkan siswa hanya aktif sebagai pendengar dan perekam informasi melalui catatan mereka. Hal tersebut mengakibatkan pelajaran menjadi tidak menarik dan membosankan bagi siswa. Selain itu kurangnya kerjasama dan komunikasi antara siswa dalam proses belajar mengajar juga merupakan salah satu penyebab rendahnya hasil belajar siswa pada materi pelajaran fisika.

Berdasarkan data dan informasi yang diperoleh dari guru mata pelajaran fisika kelas VIII, bahwa kelas yang memperoleh nilai ratarata hasil belajar fisika pada semester ganjil dan genap tahun 2 012/2013 yang masih dibawah standar ketuntasan minimum salah satunya adalah kelas VIII B dengan jumlah siswa yang memiliki nilai dibawah standar rata-rata $(70,0)$ berjumlah 12 orang dari 19 siswa atau sekitar $63,16 \%$. Sedangkan jumlah siswa yang nilaianya sudah berada di atas standar rata-rata berjumlah 7 orang atau sekitar 36,84\%. Jika dilihat perbandingan persentase ketuntasan siswa dikelas tersebut masih tergolong rendah. Untuk mengatasi kesulitan belajar siswa seorang guru dituntut untuk memiliki kemampuan mengembangkan model pembelajaran yang efektif terutama pada mata pelajaran fisika.

Sesuai dengan uraian permasalahan di atas, diterapkan suatu model pembelajaran yang dapat mengaktifkan siswa yaitu model pembelajaran kooperatif tipe artikulasi. Model pembelajaran ini menuntut siswa aktif dalam pembelajaran dimana siswa dibentuk menjadi kelompok kecil. Masing-masing siswa dalam kelompok tersebut mempunyai tugas mewawancarai teman kelompoknya tentang materi yang baru dibahas. Pembelajaran kooperatif tipe artikulasi prosesnya seperti pesan berantai, artinya apa yang telah diberikan guru, seorang siswa wajib meneruskan menjelaskannya pada siswa lain (teman kelompoknya). Siswa dituntut untuk bisa berperan sebagai "penerima pesan" sekaligus berperan sebagai "penyampai pesan" [1].

Berdasarkan penelitian sebelumnya, model pembelajaran ini pernah diterapkan oleh Mujiati dan diperoleh kesimpulan bahwa terdapat perbedaan hasil belajar fisika antara siswa yang mengikuti model pembelajaran kooperatif tipe artikulasi dengan pembelajaran konvensional pada siswa kelas VIII SMP Negeri 14 Palu, yang mana hasil belajar fisika siswa yang mengikuti pembelajaran kooperatif tipe artikulasi lebih meningkat dibandingkan siswa yang mengikuti pembelajaran konvensional [2].

Hipotesis tindakan pada penelitian ini adalah penerapan model pembelajaran kooperatif tipe artikulasi dapat meningkatkan hasil belajar fisika pada siswa kelas VIII B SMP Negeri 2 Marawola.

\section{METODOLOGI PENELITIAN}

Penelitian ini merupakan penelitian tindakan kelas (PTK) yang dilakukan dalam dua siklus. Masing-masing siklus melalui tahap perencanaan, pelaksanaan, observasi dan refleksi. Tahapan penelitian ni diadopsi dari alur PTK model Kurt Lewin yang dikembangkan oleh Mc. Taggart [3].

Subyek penelitian ini adalah seluruh siswa kelas VIII B SMP Nageri 2 Marawola yang terdaftar pada semester ganjil tahun ajaran $2012 / 2013$ yang berjumlah 19 orang siswa yang terdiri dari 8 orang siswa laki-laki dan 11 orang siswa perempuan, metode pengumpulan data pada penelitian ini, meliputi beberapa cara yaitu, observasi menggunakan lembar observasi dan tes hasil belajar. Faktor-faktor yang diteliti dalam penelitian ini adalah aktivitas guru, aktivitas siswa, afektif siswa dan kinerja kelompok siswa, serta hasil belajar siswa. Analisa data terbagi menjadi dua kelompok yaitu analisa data kuantitatif dan data kualitatif.

\section{HASIL DAN PEMBAHASAN}

Data hasil analisis observasi aktivitas guru siklus I dan siklus II dapat dilihat pada Tabel 1.

Tabel 1. Hasil Analisis Observasi Aktivitas Guru Siklus I dan siklus II

\begin{tabular}{|c|c|c|c|}
\hline Siklus & Pertemuan & $\begin{array}{c}\text { Rerata } \\
\text { Aktivitas } \\
\text { Guru (\%) }\end{array}$ & Kategori \\
\hline \multirow{3}{*}{ Satu } & Pertama & 87,50 & Baik \\
\cline { 2 - 4 } & Kedua & 91,67 & $\begin{array}{c}\text { Sangat } \\
\text { Baik }\end{array}$ \\
\hline
\end{tabular}


ISSN 23383240

\begin{tabular}{|c|c|c|c|}
\hline \multirow{2}{*}{ Dua } & Pertama & 97,92 & $\begin{array}{c}\text { Sangat } \\
\text { Baik }\end{array}$ \\
\cline { 2 - 4 } & Kedua & 100 & $\begin{array}{c}\text { Sangat } \\
\text { Baik }\end{array}$ \\
\hline
\end{tabular}

Berdasarkan Tabel 1 dapat ketahui bahwa persentase nilai rata-rata aktivitas guru siklus I pada pertemuan pertama berada pada kategori baik sedangkan pada pertemuan kedua berada pada kategori sangat baik. Pada siklus II persentase nilai rata-rata aktivitas guru pada pertemuan pertama dan kedua berada pada kategori sangat baik.

Data hasil analisis observasi aktivitas siswa siklus I dan siklus II dapat dilihat pada Tabel 2 .

Tabel 2. Hasil Analisis Observasi Aktivitas Siswa Siklus I dan siklus II

\begin{tabular}{|c|c|c|c|}
\hline Siklus & Pertemuan & $\begin{array}{c}\text { Rerata } \\
\text { Aktivitas } \\
\text { Siswa } \\
(\%)\end{array}$ & Kategori \\
\hline \multirow{2}{*}{ Satu } & Pertama & 67,50 & Kurang \\
\cline { 2 - 4 } Dua & Kedua & 75,00 & Cukup \\
\cline { 2 - 4 } & Pertama & 85,00 & Baik \\
\hline \multirow{2}{*}{ Kedua } & 92,50 & $\begin{array}{c}\text { Sangat } \\
\text { Baik }\end{array}$ \\
\hline
\end{tabular}

Berdasarkan Tabel 2 dapat diketahui bahwa persentase nilai rata-rata aktivitas siswa siklus I pada pertemuan pertama berada pada kategori kurang sedangkan pada pertemuan kedua berada pada kategori cukup. Pada siklus II persentase nilai rata-rata aktivitas siswa pada pertemuan pertama berada pada kategori baik sedangkan pada pertemuan kedua berada pada kategori sangat baik.

Data hasil analisis observasi penilaian afektif siswa siklus I dan siklus II dapat dilihat pada Tabel 3.

Tabel 3. Hasil Analisis Penilaian Afektif Siswa Siklus I dan siklus II

\begin{tabular}{|c|c|c|c|}
\hline Siklus & Pertemuan & $\begin{array}{c}\text { Rerata } \\
\text { Afektif } \\
\text { Siswa } \\
(\%)\end{array}$ & Kategori \\
\hline \multirow{2}{*}{ Satu } & Pertama & 74,66 & Cukup \\
\cline { 2 - 4 } & Kedua & 80,25 & Baik \\
\hline
\end{tabular}

\begin{tabular}{|c|c|c|c|}
\hline \multirow{3}{*}{ Dua } & Pertama & 83,22 & Baik \\
\cline { 2 - 4 } & Kedua & 90,13 & $\begin{array}{c}\text { Sangat } \\
\text { Baik }\end{array}$ \\
\hline
\end{tabular}

Berdasarkan Tabel 3 dapat diketahui bahwa persentase nilai rata-rata keberhasilan afektif siswa siklus I pada pertemuan pertama berada pada kategori cukup sedangkan pada pertemuan kedua berada pada kategori baik. Pada siklus II persentase nilai rata-rata aktivitas siswa pada pertemuan pertama berada pada kategori baik sedangkan pada pertemuan kedua berada pada kategori sangat baik.

Data hasil analisis observasi penilaian kinerja kelompok siswa siklus I dan siklus II dapat dilihat pada Tabel 4.

Tabel 4. Hasil Analisis Penilaian Kinerja Kelompok Siswa Siklus I

\begin{tabular}{|c|c|c|c|}
\hline Siklus & Pertemuan & $\begin{array}{c}\text { Rerata } \\
\text { Kinerja } \\
\text { Kelompok } \\
\text { Siswa (\%) }\end{array}$ & Kategori \\
\hline \multirow{2}{*}{ Satu } & Pertama & 77,19 & Cukup \\
\cline { 2 - 4 } Dua & Kedua & 79,39 & Cukup \\
\cline { 2 - 4 } & Pertama & 87,72 & Baik \\
\hline \multirow{2}{*}{ Kedua } & 93,86 & $\begin{array}{c}\text { Sangat } \\
\text { Baik }\end{array}$ \\
\hline
\end{tabular}

Berdasarkan Tabel 4 dapat diketahui bahwa persentase nilai rata-rata keberhasilan kinerja kelompok siswa siklus I pada pertemuan pertama dan kedua berada pada kategori cukup. Pada siklus II persentase nilai rata-rata keberhasilan kinerja kelompok siswa pada pertemuan pertama berada pada kategori baik sedangkan pada pertemuan kedua berada pada kategori sangat baik.

Data hasil belajar siswa siklus I dan siklus II secara lengkap ditunjukkan oleh Tabel 5.

Tabel 5. Hasil Belajar Siswa Siklus I dan Siklus II

\begin{tabular}{|c|l|c|c|}
\hline \multirow{2}{*}{ No. } & \multirow{2}{*}{ Aspek Perolehan } & \multicolumn{2}{|c|}{ Hasil } \\
\cline { 3 - 4 } & & Siklus I & Siklus II \\
\hline 1. & Skor maksimal & 15 & 15 \\
\hline 2 & Skor tertinggi & 14 & 15 \\
\hline
\end{tabular}




\begin{tabular}{|c|l|c|c|}
\hline 3 & $\begin{array}{l}\text { Banyaknya siswa } \\
\text { yang memperoleh } \\
\text { skor tertinggi }\end{array}$ & 1 orang & 2 orang \\
\hline 4 & Skor terendah & 6 & 9 \\
\hline 5 & $\begin{array}{l}\text { Banyaknya siswa } \\
\text { yang memperoleh } \\
\text { skor terendah }\end{array}$ & 1 orang & 1 orang \\
\hline 6 & $\begin{array}{l}\text { Banyaknya siswa } \\
\text { yang tuntas }\end{array}$ & $\begin{array}{c}14 \\
\text { orang }\end{array}$ & 17 orang \\
\hline 7 & $\begin{array}{l}\text { Banyaknya siswa } \\
\text { yang tidak tuntas }\end{array}$ & 5 orang & 2 orang \\
\hline 8 & $\begin{array}{l}\text { Persentase daya } \\
\text { serap klasikal }\end{array}$ & $\begin{array}{c}72,98 \\
\%\end{array}$ & $85,26 \%$ \\
\hline 9 & $\begin{array}{l}\text { Persentase } \\
\text { ketuntasan belajar } \\
\text { klasikal }\end{array}$ & $\begin{array}{c}73,68 \\
\%\end{array}$ & $89,47 \%$ \\
\hline
\end{tabular}

Berdasarkan analisa tes hasil belajar yang dilakukan pada siklus I, diketahui bahwa hasil belajar fisika siswa kelas VIII B SMP Negeri 2 Marawola sudah cukup baik, hanya ada 5 siswa yang tidak tuntas dari 19 siswa sedangkan ketuntasan belajar klasikal (KBK) siswa mencapai $73,68 \%$ dan daya serap klasikal (DSK) siswa mencapai $72,98 \%$, akan tetapi hasil ini belum memenuhi indikator standar ketuntasan belajar klasikal dan daya serap klasikal yang harus mencapai $80 \%$.

Kekurangan dari pembelajaran pada siklus I adalah: (a) Guru kurang maksimal dalam menjelaskan kembali materi yang belum dipahami siswa yang disajikan; (b) Siswa belum seluruhnya siap menerima materi dan siswa belum sepenuhnya mampu memahami materi yang diterimanya; (c) Sebagian siswa masih ada yang ragu-ragu untuk bertanya terkait dengan materi yang dibahas; (d) Sebagian siswa belum membuat catatan-catatan kecil dan membuat ringkasan dari hasil wawancara dengan teman kelompoknya untuk dipaparkan di depan kelas; (e) Siswa kurang mampu menyimpulkan materi yang telah dipelajari dan sebagian besar siswa tidak mampu menyelesaikan soal-soal pemahaman konsep.

Dilihat dari hasil observasi aktivitas guru dan siswa diketahui bahwa tidak tuntasnya hasil belajar siswa ini disebabkan oleh beberapa faktor yaitu guru kurang maksimal dalam menjelaskan kembali materi yang belum dipahami siswa yang disajikan. Guru belum menjelaskan materi secara singkat dan jelas sehingga siswa kurang mengerti oleh penjelasan guru dan guru kurang maksimal meminta siswa melengkapi catatan-catatan yang diperoleh dari hasil wawancara dan juga guru belum menyediakan waktu yang cukup kepada siswa untuk bertanya. Siswa kurang memberi tanggapan pada kelompok penyaji dan kurang mencatat jawaban yang diberikan oleh kelompok penyaji. Guru kurang maksimal dalam memotivasi siswa dan menyampaikan informasi kepada siswa tentang penerapan pembelajaran kooperatif tipe artikulasi. Guru kurang memancing siswa untuk bertanya atau mengajukan pertanyaan sehingga siswa kurang aktif dalam kegiatan pembelajaran. Sebagian siswa belum membuat catatan-catatan kecil dan membuat ringkasan dari hasil wawancara dengan teman kelompoknya untuk dipaparkan di depan kelas. Siswa kurang mampu menyimpulkan materi yang telah dipelajarai dan juga siswa belum seluruhnya siap menerima materi. Sebagaimana dapat dilihat dari hasil analisis aktivitas guru yang berada pada kategori baik dan aktivitas siswa yang masih berada pada kategori kurang dan cukup. Hal ini dapat dilihat pada Gambar 1.

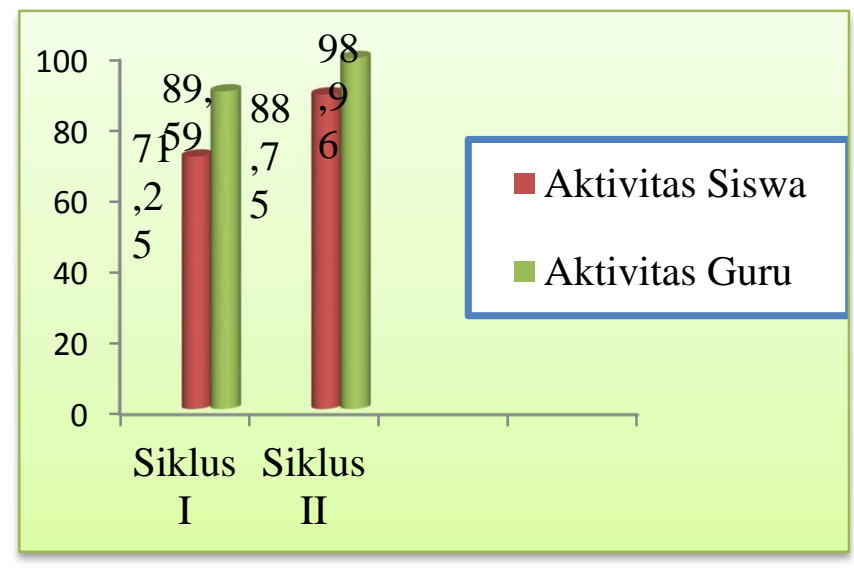

Gambar 1. Grafik Aktivitas Siswa dan Aktivitas Guru

Dari hasil penilaian afektif siswa dan kinerja kelompok juga diketahui beberapa hal: (a) Masih ada beberapa siswa yang sering terlambat dalam mengikuti pelajaran; (b) Siswa kurang perhatian dan kurang berkonsentrasi dalam mengikuti pelajaran; (c) Siswa kurang memberikan 
pertanyaan; (d) Siswa masih jarang menyelesaikan tugas dan tugas diserahkan kurang rapi; (e) Sebagian besar kelompok kurang membantu ketika ada temannya yang kesulitan; (f) Sebagian besar kelompok kurang bekerja sama dan kurang tukar pendapat; $(\mathrm{g})$ Sebagian kelompok masih belum mampuh menjawab pertanyaan dengan tepat. Dari hasil analisis afektif siswa dan kinerja kelompok diketahui bahwa aspek-aspek yang diamati masih berada pada kategori baik dan cukup. Dari beberapa penyebab yang dikemukakan di atas, guru harus lebih berusaha untuk memperbaiki kemampuan dalam mengelolah kelas dengan baik agar kemampuan siswa bisah lebih meningkat.

Pembelajaran pada siklus II dilaksanakan untuk memperbaiki pembelajaran pada siklus I. Pelaksanaan pembelajaran pada siklus II berjalan lancar sesuai dengan rencana. Siswa terlihat lebih aktif melakukan kegiatan pembelajaran. Pada siklus II, guru berusaha meminimalisir beberapa penyebab yang mengakibatkan hasil belajar siswa pada siklus I belum memenuhi indikator keberhasilan kuantitatif dan kualitatif, agar bisa meningkat dan bisa memenuhi standar tersebut. Beberapa usaha yang dilakukan diantaranya: guru lebih mendisiplinkan siswa seperti menanyakan kesiapan siswa untuk menerima materi sebelum pembelajaran dimulai setelah semua siswa sudah siap menerima materi barulah pembelajaran dimulai. Guru lebih memperhatikan kemampuan siswa dalam menerima materi dan menjelaskan kembali materi yang belum dipahami siswa secara singkat dan jelas. Guru memotivasi siswa untuk berani mengajukan pertanyaan sekiranya ada materi yang belum dipahami dan berani menjawab pertanyaan dari guru atau temannya. Guru meningkatkan bimbingan dan kontrol atas kerjasama siswa dalam kegiatan wawancara dan pengerjaan LKS secara kelompok.

Berdasarkan analisis tes hasil belajar siklus II, diketahui bahwa hasil belajar siswa sudah memenuhi indikator keberhasilan kuantitatif dengan ketuntasan belajar klasikal (KBK) siswa mencapai $89,47 \%$ dan daya serap klasikal (DSK) siswa mencapai 85,26 \% dimana hanya ada 2 siswa yang tidak tuntas dari 19 siswa. Dari hasil analisis kualitatif diketahui bahwa peran siswa yang sesuai dengan skenario pembelajaran dalam kegiatan pembelajaran telah terarah dengan baik. Hal ini dapat dilihat dari hasil analisis lembar observasi aktivitas guru dan siswa yang mengalami peningkatan yaitu berada pada kategori sangat baik dan baik, sedangkan penilaian afektif dan kinerja kelompok juga mengalami peningkatan yaitu berada pada kategori baik dan sangat baik.

Hasil yang diperoleh pada siklus II dapat meningkat dan lebih baik dari siklus I karena faktor-faktor penyebab kegagalan pada siklus I dapat diminimalisir. Peningkatan hasil belajar siswa dari siklus I ke siklus II dapat dilihat pada Gambar 2.

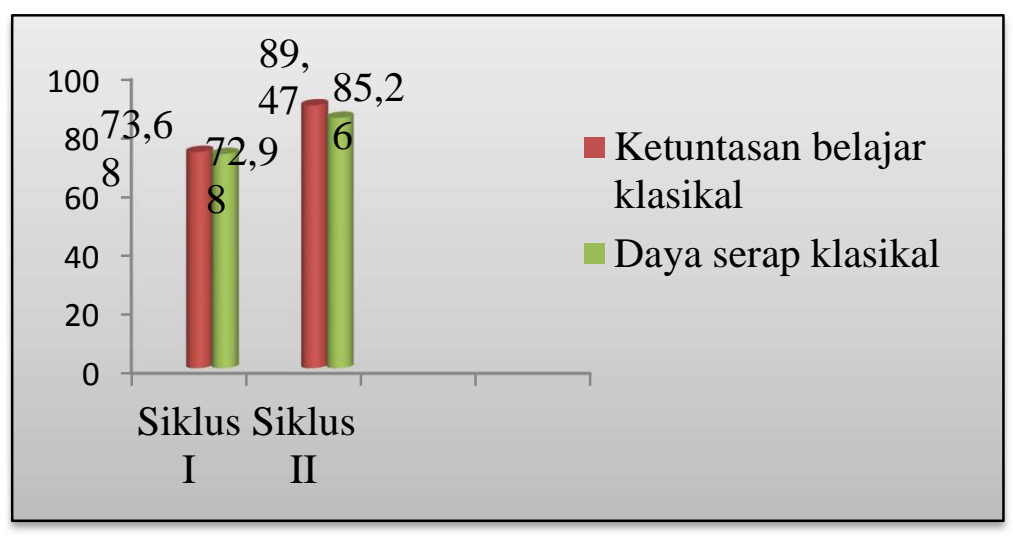

\section{Gambar 2. Grafik Hasil Belajar Siswa Siklus I dan II}

Berdasarkan Gambar 2 diketahui bahwa peningkatan daya serap klasikal dan ketuntasan belajar klasikal dari siklus I ke siklus II sebesar $16,82 \%$ dan $21,43 \%$. Berdasarkan uraian di atas, dapat dikatakan bahwa model pembelajaran kooperatif tipe artikulasi dapat meningkatkan hasil belajar fisika siswa kelas VIII B SMP Negeri 2 Marawola.

\section{KESIMPULAN}

Berdasarkan hasil analisis data penelitian tindakan kelas ini dapat disimpulkan bahwa penerapan model pembelajaran kooperatif tipe artikulasi dapat meningkatkan hasil belajar fisika pada siswa kelas VIII B SMP Negri 2 Marawola. Hal ini ditunjukan pada hasil siklus I diperoleh ketuntasan belajar klasikal sebesar 73,68 \% serta daya serap klasikal sebesar 72,98 \%. 
Mengalami peningkatan pada siklus II dengan ketuntasan belajar klasikal sebesar 89,47 \% serta daya serap klasikal sebesar 85,26 \%. Peningkatan ketuntasan belajar klasikal (KBK) dan daya serap klasikal (DSK) dari siklus I ke siklus II sebesar $21,43 \%$ dan $16,82 \%$. Hasil observasi aktivitas siswa dan guru pada siklus I berada pada kategori cukup dan baik. Aktivitas siswa dan guru ini mengalami peningkatan pada siklus II yaitu berada pada kategori baik dan sangat baik.

\section{DAFTAR PUSTAKA}

[1] Suyatno. 2008. Langkah-langkah Pembelajaran Artikulasi. Bandung: Remaja Rosdakarya

[2] Mujiati. 2012. Perbedaan Hasil Belajar Fisika Antara Penerapan Model Pembelajaran Kooperatif Tipe Artikulasi Dengan Pembelajaran Konvensional Pada Siswa Kelas VIII SMP Negeri 14 Palu. Skirpsi tidak dipublikasikan. Palu: FKIP UNTAD.

[3] Depdiknas. 2004. Penelitian Tindakan Kelas. Jakarta: Direktorat Pendidikan Nasional. 